\title{
MATERIAŁY DO NAUCZANIA NIEMIECKIEGO JĘZYKA GOSPODARKI DLA PRZYSZZYCH TŁUMACZY ORAZ ICH STRUKTURA
}

Zarys treści: Artykuł jest próbą opisania materiałów do nauczania niemieckiego języka gospodarki dla przyszłych tłumaczy oraz struktury takiego materiału. Przyszli tłumacze powinni nabyć nie tylko wiedzę z zakresu języka specjalistycznego gospodarki, lecz również wiedzę fachową z tej dziedziny w zakresie podstawowym. W przypadku niniejszej koncepcji chodzi o teksty stosowane w ramach działalności przedsiębiorstwa handlowego. Proponowane materiały wykorzystane mają być w podręczniku, składającym się z części zawierającej teksty i ćwiczenia, klucz oraz glosariusz dwujęzyczny.

\section{Wstęp}

Celem niniejszego artykułu jest przedstawienie materiałów do nauczania Uniemieckiego języka gospodarki dla przyszłych tłumaczy oraz struktury tych materiałów. Przyszli tłumacze stanowią o tyle specyficzną grupę docelową, iż wykazują się wysoką kompetencją językową w ramach docelowego języka ogólnego, nie dysponują natomiast ani kompetencją językową w ramach docelowego języka specjalistycznego, ani wiedzą fachową w danej dziedzinie.

Nauczanie języka specjalistycznego to jednocześnie nauczanie danego języka specjalistycznego i przekazywanie pewnego zasobu wiedzy fachowej, ponieważ języka fachowego i dziedziny fachowej nie można od siebie oddzielić (por. Schröder 1986: 113). W związku z tym należy zastanowić się, jakim 
zakresem wiedzy fachowej powinien dysponować tłumacz, by móc dobrze wykonywać swój zawód. Praktyka pracy tłumacza pokazuje, że nie pracuje on jedynie z jednym, lecz z wieloma językami specjalistycznymi. Również w trakcie kształcenia ma do czynienia nie z jednym, lecz wieloma językami specjalistycznymi. Nie ma jednakże stać się ekspertem w danej dziedzinie, dlatego też zasadne wydaje się przekazywanie w danej dziedzinie specjalistycznej, tutaj gospodarki, wiedzy podstawowej. Hans-Rüdiger Fluck (1992: 223) uważa, że bez wiedzy fachowej trudno jest tłumaczyć teksty specjalistyczne, przy czym przekazywanie wiedzy z różnych dziedzin nie powinno służyć odpowiednio wczesnej i jednostronnej specjalizacji, lecz zapoznaniu się z egzemplarycznymi podstawowymi wiadomościami, które w przyszłości umożliwią szybkie opracowanie danego tekstu specjalistycznego pod względem językowym i fachowym. Posiadanie wiedzy, przynajmniej podstawowej, w danej dziedzinie ma również zapobiec popełnianiu przez tłumacza rażących błędów. Dlatego chodzi o to, by w trakcie nauczania języka specjalistycznego pomóc tłumaczowi stworzyć podstawę do rozpoznawania takich pułapek tłumaczeniowych (por. Thomsen 1991: 425), uwrażliwić na istnienie problemów terminologicznych, pomóc mu wypracować metody ich rozwiązywania, w rezultacie więc umożliwić mu adekwatne tłumaczenie tekstów specjalistycznych.

Wybierając materiał językowy na cele takiego nauczania, powinno się więc uwzględnić taki materiał, który umożliwiłby przyszłym tłumaczom nabycie wiedzy fachowej w zakresie podstawowym, czyli odpowiadającym materiałowi omawianemu $\mathrm{w}$ trakcie pierwszych semestrów danych studiów kierunkowych, określanemu często jako „Wstęp do...”. Należy więc stwierdzić, z jakich obszarów rzeczywistości fachowej pochodzić powinien ten materiał. W przypadku niniejszej koncepcji chodzi o teksty stosowane w ramach działalności przedsiębiorstwa handlowego. Opisana poniżej teoria określenia dziedziny gospodarki przy pomocy struktur komunikacyjnych modelowego przedsiębiorstwa przeznaczona jest przede wszystkim na potrzeby nauczania języka specjalistycznego gospodarki dla przyszłych tłumaczy, po rozszerzeniu i/lub uzupełnieniu mogłaby jednakże posłużyć jako podstawa do badań nad językiem specjalistycznym gospodarki.

Sama dziedzina gospodarki jest bardzo rozległa i kompleksowa, dlatego też trudne jest zdefiniowanie tego, czym jest język specjalistyczny gospodarki. Próbuje się rozwiązać problem jego heterogeniczności przez określanie go nie jako kompleksowej całości, lecz jako szeregu subjęzyków funkcjonujących w ramach języka gospodarki. Subjęzyki te definiowane są różnorodnie przez poszczególnych autorów. Raz klasyfikowane są one odpowiednio do podziału nauk ekonomicznych, istniejącego np. w krajach niemieckojęzycznych, dlate- 
go też mowa tu jest o języku BWL, czyli ekonomiki przedsiębiorstwa, czy też VWL, tzn. ekonomii (np. Buhlmann, Fearns 1987: 306), innym razem przyporządkowane są poszczególnym poddziedzinom ekonomiki przedsiębiorstwa i wtedy mowa jest o języku produkcji, zbytu, reklamy itp. (np. Bungarten 1988: 19).

W codziennej komunikacji handlowo-ekonomicznej nikt nie porozumiewa się tylko w jakimś jednym subjęzyku, tak więc należałoby spróbować określić ten język jako kompleksową całość, przede wszystkim z uwagi na wspomniane powyżej aspekty dydaktyczno-metodyczne. Poza tym zarówno w ramach ekonomiki przedsiębiorstwa, jak i ekonomii nie ma jednoznacznych koncepcji pojmowania swojego przedmiotu. Na przykład w obszarze anglojęzycznym negowany jest podział na ekonomikę przedsiębiorstwa i ekonomię, mówi się tam tylko o jednej dziedzinie: economy. W krajach niemieckojęzycznych istnieje co najmniej pięć koncepcji rozumienia dziedziny ekonomiki przedsiębiorstwa. Jeśli więc specjaliści mają problemy ze zdefiniowaniem swojej właściwej dziedziny badawczej, tym bardziej jest trudne dla lingwisty zdecydowanie się na jedną $\mathrm{z}$ istniejących koncepcji, by ją wykorzystać jako podstawę do określenia tego, czym jest język specjalistyczny gospodarki.

Optymalnym sposobem określenia tego, czym jest język gospodarki, nie jest więc przyjęcie jednej z wymienionych wyżej koncepcji, lecz wybranie takiego wycinka dziedziny handlowo-ekonomicznej, który byłby reprezentatywny dla niej jako całości. Taki wycinek stanowi przedsiębiorstwo handlowe wraz ze swoimi strukturami komunikacyjnymi. Jest ono taką częścią krwiobiegu gospodarki, która ma do czynienia z jej wszystkimi częściami składowymi i dlatego można ją uznać za reprezentatywną dla tej dziedziny. Struktury komunikacyjne przedsiębiorstwa można podzielić nie tylko odpowiednio do jego poszczególnych działów, z czym można się spotkać w niektórych podręcznikach do nauki języka specjalistycznego gospodarki (np. w podręczniku J. Boltena Marktchance Deutsch), lecz na zakresy tematyczne. Niniejszy model zawiera osiem zakresów tematycznych, które z kolei odzwierciedlają pracę przedsiębiorstwa od momentu jego założenia do momentu likwidacji. Każdemu zakresowi przyporządkowano teksty - łącznie dwadzieścia osiem - powiązane ze sobą merytorycznie, jak np. teksty z drugiego zakresu tematycznego „Transakcja kupna-sprzedaży”. W ramach tego zakresu można prześledzić poszczególne etapy realizacji transakcji kupna-sprzedaży od chwili wysłania zapytania ofertowego, poprzez otrzymanie oferty, wysłanie zamówienia, podpisanie umowy, do powstania ewentualnych trudności w jej realizacji, np. otrzymania reklamacji.

Wszystkie wybrane na potrzeby podręcznika teksty powinny być podda- 
ne analizie, by w jej rezultacie oprócz aspektów językowych wykazać funkcje danych tekstów i ich kontekst sytuacyjny. Metoda analizy składa się z trzech elementów: konstelacji komunikacyjnej, makrostruktury i mikrostruktury tekstu. Zbadanie konstelacji komunikacyjnej ma dostarczyć odpowiedzi na pytania, kim jest nadawca tekstu, kim jest odbiorca, czego tekst dotyczy i jakie są intencje jego autora. W ramach makrostruktury tekstu ma zostać zanalizowana jego struktura, natomiast w ramach mikrostruktury jego gramatyka i leksyka. Zarówno więc dobór tekstów, jak i metody analizy zapewniają pozyskanie wiedzy specjalistycznej i środków językowych adekwatnych do przekazania uczniom niezorientowanym $\mathrm{w}$ danej dziedzinie specjalistycznej, nieznających ani kontekstu sytuacyjnego, ani wzajemnych zależności pomiędzy tekstami, a o takich właśnie uczniów chodzi w przypadku kształcenia przyszłych tłumaczy.

Proponowane materiały mają być wykorzystane w podręczniku składającym się z części zawierającej teksty i ćwiczenia, klucz oraz glosariusz dwujęzyczny, wypełniany samodzielnie przez uczących się. Poniżej przedstawiona jest struktura tych materiałów.

\section{Materiały do nauczania oraz ich struktura}

Ćwiczenia oraz ich układ w nauczaniu języka specjalistycznego charakteryzują się jedną istotną cechą, która odróżnia je od tych stosowanych w nauczaniu języka ogólnego: są one wtopione w konkretne uwarunkowania danego języka specjalistycznego, skutkiem czego uwzględniają elementy sytuacji fachowych. Tym samym zorientowane są m.in. na szczególne cechy fachowej komunikacji na poziomie pragmatycznym, semantycznym i syntaktycznym, na określoną grupę docelową i określone kwalifikacje.

Jeśli chodzi o fachowe i językowe uwarunkowania oraz sytuacje i teksty, to wiąże się z nimi pytanie o językową i fachową autentyczność ćwiczeń. Określone sytuacje powinny być konsekwentnie uwzględniane nie tylko w tekstach, lecz i ćwiczeniach. Ponadto należy odpowiedzieć na pytanie, czy teksty specjalistyczne występują w materiałach wyjściowych i/lub docelowych i czy korzysta się z dodatkowych materiałów fachowych. W wypadku sytuacji fachowych należy przewidzieć ćwiczenia dotyczące typowych dla nich środków językowych (leksykalnych i syntaktycznych). Jeśli chodzi o ćwiczenia na poziomie słowotwórstwa i składni, to można dokonywać różnych operacji na bazie materiału wyjściowego.

Odnośnie do grupy docelowej należy stwierdzić, czy trzeba uwzględnić 
inne języki jako docelowe, do jakiego poziomu kompetencji językowej i fachowej mają być dopasowane ćwiczenia, następnie stopień złożoności ćwiczeń, jak często pojawiają się odpowiednie operacje oraz umiejscowienie ćwiczeń w konkretnych sytuacjach komunikacyjnych. W ramach ćwiczenia jednostek leksykalnych należy wykorzystywać w miarę systematycznie już poznane związki systemowe i logiczne (por. Beier, Möhn 1983: 220 i n.).

W zakresie docelowych umiejętności, względnie językowo-komunikacyjnych sprawności, rodzaj ćwiczeń zależy od sprawności, na które kładzie się nacisk - ćwiczenia powinny być więc ukierunkowane na nabywanie odpowiednich sprawności. Nie należy jednak ćwiczyć wielu sprawności na tym samym tekście, określone sprawności mogą się jednakże wzajemnie wspierać, co może zwiększyć efekt nauczania. W rzeczywistości fachowej na podstawie już istniejących tekstów tworzy się nowe, przy czym materiał językowy (na poziomie strukturalnym, semantycznym i pragmatycznym) stosowany jest dla nowych tekstów. Poza tym polecenia w ćwiczeniach powinny być formułowane w sposób możliwie zbliżony do rzeczywistości fachowej (por. Beier, Möhn 1988: 53).

Opierając się na katalogu kryteriów dla opisu ćwiczeń w ramach nauczania języków specjalistycznych (Beier, Möhn 1983) można przedstawić następującą strukturę ćwiczeń stosowanych w nauczaniu niemieckiego języka gospodarki dla przyszłych tłumaczy.

Najpierw należy podkreślić, że ćwiczenia są bardzo złożonym problemem i mogą wykazywać się całym szeregiem charakterystycznych cech. Zasadniczo chodzi tutaj o cechy w zakresie rozwiązania i podstawy oraz o stosowanie takich samych lub różnych systemów znaków (por. Beier, Möhn 1983: 208 i n.).

W odniesieniu do podstawy chodzi o takie elementy ćwiczeń jak materiał wyjściowy i polecenie, ich forma i funkcja. W obszarze rozwiązania chodzi ogólnie o użycie znaków językowych, o język danej dziedziny fachowej, względnie sytuacji fachowych. W niniejszej koncepcji przewiduje się ćwiczenie znaków językowych w formie znaków pisanych, form gramatycznych, słowotwórstwa, słów, zdań i tekstów. Poziom znaków dźwiękowych mógłby być uwzględniony po opracowaniu odpowiednich materiałów.

Materiał wyjściowy i polecenia należą do istotnych elementów sterowania w nauczaniu języków specjalistycznych. Trzy istotne aspekty materiału wyjściowego to: znaczenie/ranga materiału wyjściowego, jego cechy i operacje dokonywane na jego podstawie. $\mathrm{W}$ niniejszej koncepcji poza materiałem wyjściowym uwzględnia się materiał dodatkowy. Jako materiał wyjściowy przewidziane są teksty pochodzące z rzeczywistości fachowej, jako materiał dodat- 
kowy - teksty będące wynikiem analizy konstelacji komunikacyjnej tekstów autentycznych; wyniki wcześniejszych ćwiczeń oraz materiał pomocniczy jak np. odpowiednie leksykony. W drugim aspekcie chodzi o językowe cechy materiału wyjściowego. W poniższej koncepcji chodzi o językowe cechy na poziomie znaków językowych, form gramatycznych, słowotwórstwa, słów, zdań i tekstów. Ponieważ docelowe sprawności można zlokalizować zarówno na płaszczyźnie receptywnej (sprawność czytania), jak i produktywnej (sprawność pisania), materiał wyjściowy tworzą zarówno teksty, jak i mniejsze jednostki, które wynikają z analizy tekstów. Jako rozwiązania pracy z mniejszymi jednostkami przewidziane są teksty, natomiast jako rozwiązanie pracy z tekstami zarówno teksty, jak i mniejsze jednostki (słowa, struktury gramatyczne). Poziom znaków dźwiękowych musiałby być dodatkowo opracowany, by możliwe było ćwiczenie dalszych sprawności.

Następny aspekt dotyczy tego, co uczący się miałby robić z materiałem wyjściowym. W ramach omawianej koncepcji mają być ćwiczone umiejętności receptywne, jak i produktywne, elementy językowe, oraz sytuacyjne, dlatego też możliwe są operacje, które odnoszą się do wszystkich tych płaszczyzn. Jednostki leksykalne ćwiczone są przy pomocy takich operacji jak przyporządkowanie, przepisanie, identyfikacja i zastąpienie. Dla sfery syntaktycznej przewiduje się ćwiczenia transformacyjne i różnorakie operacje, m.in. przyporządkowanie, zastąpienie, uzupełnienie lub rozszerzenie. W sferze morfologicznej występują takie operacje jak złożenie, powiązanie, opuszczenie lub przyporządkowanie. Operacje polegające na przyporządkowaniu czy identyfikowaniu, dokonywane przy pomocy jednego tekstu, wskazują raczej na receptywny charakter ćwiczenia, z kolei takie jak np. rozszerzenie na produktywny. Oczywiście można kombinować te operacje i łączyć w jednym ćwiczeniu.

W niniejszej koncepcji należałoby zastosować jednoznaczne polecenia, sformułowane w sposób prosty lub kompleksowy. Kompleksowość polecenia zależy od kompleksowości ćwiczenia, np. kiedy polecenie zawiera zawezwanie do wykonania jednej lub też kilku operacji. Z tym wiąże się pytanie o stopień sterowania rozwiązaniem. $Z$ jednej strony, czy możliwe jest tylko jedno, czy też wiele rozwiązań, z których należy wybrać, i z drugiej, czy możliwych jest wiele adekwatnych rozwiązań. By sprostać żądaniu możliwie dużego zbliżenia do komunikacji autentycznej, optymalną drogą wydaje się stopniowe zastępowanie ćwiczeń z jednym lub wieloma rozwiązaniami, z których można wybierać, ćwiczeniami z wieloma adekwatnymi rozwiązaniami. Przy pomocy dwóch pierwszych rodzajów można ćwiczyć inwentarz językowy na poziomie słownictwa, morfologii i gramatyki, natomiast przy pomocy trze- 
ciego rodzaju - produkcję tekstów w konkretnych sytuacjach. Tutaj musi być również rozstrzygnięte pytanie o istnienie klucza. Podawanie rozwiązania jest trudne, kiedy możliwych jest wiele adekwatnych rozwiązań jednego zadania, co w przypadku tekstów jest częste. Ponieważ tak jest w niniejszej koncepcji, możliwe jest podanie klucza jedynie dla części ćwiczeń, a mianowicie dla tej, która dotyczy ćwiczenia środków językowego inwentarza oraz struktur gramatycznych. Wiąże się z tym pytanie o rodzaj sterowania, tzn. sposób, w jaki wpływa się na rozwiązania, których dokonuje uczący się. W przypadku gdy mają być ćwiczone aspekty formalno-językowe, których opanowanie jest warunkiem użycia języka zgodnie z sytuacją, chodzi o taki rodzaj sterowania, kiedy w poleceniach i w materiale wyjściowym zawarte są lingwistyczne reguły, definicje, inne metajęzykowe dane, środki językowe, których należy użyć, i tym samym zaprezentowane wzory rozwiązań. Jeśli chodzi o ćwiczenia, których rozwiązania są tekstami, polecenia powinny być sformułowane mniej rygorystycznie i podane jedno przykładowe rozwiązanie lub kilka adekwatnych. Wszystkie rozwiązania powinny się znajdować w tym samym tomie co ćwiczenia, najlepiej w jego ostatniej części.

Inny rodzaj sterowania dotyczy podania cech sytuacji użycia języka, przez co znane są warunki, które w pozalekcyjnej rzeczywistości znacznie wpływają na wybór, użycie i częstotliwość występowania danych środków językowych. W czasie tworzenia takich ćwiczeń muszą być m.in. uwzględnione również wyniki dokonanych analiz tekstów (materiał dodatkowy w postaci tekstów będących wynikiem analizy konstelacji komunikacyjnej tekstów pochodzących z praktyki fachowej) oraz następujące cechy sytuacji użycia języka: medium, liczba partnerów komunikacji oraz ich funkcja/rola, wiedza odbiorcy, fachowy zakres komunikacyjny, poziom abstrakcji, elementy strategii komunikacyjnych, jak np. definiowanie, omawianie, wyjaśnianie, komentowanie, uzasadnianie, pytanie i odpowiadanie. Takie elementy strategii komunikacyjnej, które dotyczą komunikacji ustnej, mogłyby być ćwiczone dopiero po opracowaniu odpowiednich materiałów. Powyższe cechy sytuacji użycia języka mogą z jednej strony pochodzić z materiału dodatkowego, który zostanie udostępniony uczącemu się, a z drugiej wynikać z analizy makrostruktury tekstów pochodzących z praktyki. Tym samym możliwe są z jednej strony takie ćwiczenia, w których uczący się wyjaśnia, definiuje pojęcia i stany rzeczy, odpowiada na pytania przy pomocy materiału dodatkowego (teksty, odpowiednie leksykony) lub wyjściowego, a $\mathrm{z}$ drugiej takie, w których pracuje wyłącznie z materiałem wyjściowym, nazywając np. funkcje tekstu, dzieląc go i przyporządkowując tytuły treści jego części składowych oraz zajmując się w jakikolwiek inny sposób jego formą (odnośnie do takich pozajęzykowych 
środków jak wyróżniki, podkreślenia). Nazwane powyżej sytuacyjne elementy sterowania służą więc ćwiczeniu użycia języka odpowiednio do sytuacji. Co prawda sytuacje użycia języka odpowiednio do rzeczywistości fachowej brane są pod uwagę w ćwiczeniach leksykalnych i tych dotyczących konstelacji komunikacyjnej tekstów, możliwe są też jednak ćwiczenia gramatyczne, uwzględniające kontekst sytuacyjny.

Po nabyciu wiedzy dotyczącej sytuacji fachowych, w których umiejscowione są teksty, wiedzy fachowej oraz przeprowadzeniu gramatycznych, semantycznych i morfologicznych ćwiczeń możliwe są ćwiczenia o charakterze produktywnym, których celem jest tworzenie tekstów.

W końcu należy omówić jeszcze element użycia tych samych lub różnych systemów znaków. Ponieważ w ramach niniejszej koncepcji grupą docelową są przyszli tłumacze, niezbędne jest włączenie drugiego języka poza niemieckim - języka polskiego. Tutaj można wyobrazić sobie przede wszystkim ćwiczenia, w których chodziłoby zarówno o kontrastywną pracę na poziomie tekstów, dotyczącą semantycznych, syntaktycznych, morfologicznych i ewentualnie sytuacyjnych elementów, jak i o kontrastywną pracę terminologiczną przy pomocy jednojęzycznych i dwujęzycznych słowników specjalistycznych. $\mathrm{Na}$ cele kontrastywnej pracy z tekstami powinno się przygotować teksty polskie. Rozwiązania ćwiczeń, których celem jest kontrastywna praca $\mathrm{z}$ materiałem językowym, mogłyby być zawarte dodatkowo w słowniczku, umieszczonym w ostatniej części podręcznika. Można sobie wyobrazić następującą strukturę słowniczka:

\begin{tabular}{|l|l|l|l|}
\hline Hasło $w$ języku & Definicja w języku & Ekwiwalent & Definicja ekwiwalen- \\
wyjściowym & wyjściowym & w języku docelowym & tu w języku docelo- \\
(niemieckim) & (niemieckim) & (polskim) & wym (polskim) \\
\hline
\end{tabular}

Słowniczek powinien zawierać hasła w języku wyjściowym, natomiast definicje w języku wyjściowym oraz ekwiwalenty i definicje w języku docelowym powinny być naniesione przez uczącego się. Każde hasło w języku wyjściowym powinno ponadto zawierać informacje o części mowy, ewentualnie rodzaju gramatycznym, liczbie, końcówce dopełniacza.

Nie należy zapominać o oddaniu w ćwiczeniach powiązań merytorycznych istniejących pomiędzy tekstami wyjściowymi - jest to jeden z najważniejszych elementów niniejszej koncepcji. Tylko w ten sposób można zagwarantować, że zachowane zostanie odniesienie do rzeczywistości pozajęzykowej. Chodziłoby więc o takie ćwiczenia, których treść nawiązywałaby do poprzed- 
nich tekstów, stanów rzeczy, i ewentualnie o takie, w których przeprowadza się różnorodne operacje na podstawie wcześniejszych tekstów.

\section{Literatura}

Beier, R., Möhn, D., 1983, „Merkmale fachsprachlicher Übungen. Beschreibungskategorien für das 'Hamburger Gutachten'", Jahrbuch Deutsch als Fremdsprache, 7/9, A. Wierlacher (red.), s. 194-228.

Beier, R., Möhn, D., 1988, „Fachsprachlicher Fremdsprachenunterricht. Voraussetzungen und Entscheidungen", Die Neueren Sprachen, 1/2, s. 19-75.

Buhlmann, R., Fearns, A., 1987, Handbuch des Fachsprachenunterrichts. Unter besonderer Berücksichtigung naturwissenschaftlich-technischer Fachsprachen, Berlin et al.: Langenscheidt KG.

Bungarten, T. (Hrsg.), 1988, Sprache und Information in Wirtschaft und Gesellschaft, Toestedt: Attikon.

Fluck, H.-R., 1992, Didaktik der Fachsprachen, Forum für Fachsprachen-Forschung, Tübingen: Gunter Narr.

Gnutzmann, C. (Hrsg.), 1988, Fachbezogener Fremdsprachenunterricht, Forum für Fachsprachen-Forschung, Tübingen: Gunter Narr.

Linden, J. (Hrsg.), 1989, Kommunikativ-funktionale Beschreibung von Fachsprachen für Lehrzwecke, Martin Luther Universität Halle-Wittenberg: Wissenschaftliche Beiträge 49/1989.

Morgenroth, K., 1993, Methoden der Fachsprachendidaktik und -analyse, Frankfurt am Main et al.: Peter Lang.

Oldenburg, H., 1992, Angewandte Fachtextlinguistik, Forum für Fachsprachen-Forschung, Tübingen: Gunter Narr.

Schröder, H., 1986, „Zur Arbeit mit sozialwissenschaftlichen Fachtexten in Sprachlehrveranstaltungen Deutsch als Fremdsprache", Jahrbuch Deutsch als Fremdsprache, 12, A. Wierlacher (red.), s. 252-263.

Thomsen, K.T., 1991, „Technisches Denken”, [w:] Interkulturelle Wirtschaftskommunikation, B.-D. Müller (red.), München, iudicium, s. 423-433.

Wierlacher, A. (red.), 1983, Jahrbuch Deutsch als Fremdsprache, 9.

Wierlacher, A. (red.), 1986, Jahrbuch Deutsch als Fremdsprache, 12. 


\section{Materials for teaching business German to translator trainees}

Summary

The major aim of this article is to present materials that are to be used in teaching business German to translator trainees. Translator trainees are a very specific target group in terms of teaching specialist language since they demonstrate high degree of general language competence, yet they still lack specialist field competence. Therefore, teaching specialist language in this specific group is to be combined with teaching certain aspects of specialist knowledge because separating language and the specialization field is hardly possible. Translator trainees are not experts, therefore they should first learn how to recognize problems in the specialization field and then seek methods of dealing with those problems effectively.

Teaching materials allow translator trainees to acquire specialist knowledge concerning their key specialization field. The concept of a book provides for the part covering reading tasks and exercises, the key and glossary; the exercises are to be filled in by students. 